\title{
Screening of mustard varieties against sucking insect pests of mustard
}

\author{
Syed Jahangeer Shah ${ }^{1 *}$, Bhai Khan Solangi ${ }^{2}$, Zulfiquar Ali ${ }^{3}$, Sajid Ali \\ Shah $^{4}$, Aziz Ullah ${ }^{5}$, Kareem Bakhsh ${ }^{6}$, Naveed Ahmed ${ }^{7}$, Naseer Ahmed ${ }^{8}$ \\ and Tariq Ali Mastoi ${ }^{9}$
}

1. ADI Institute Usta Muhammad, Jaffrabad Balochistan-Pakistan

2. Department of Entomology, Sindh Agriculture University, Tandojam-Pakistan

3. Directorate of Agriculture Research Jaffrabad at Usta Muhammad-Pakistan

4. Department of Entomology, Sindh Agriculture University, Tandojam-Pakistan

5. Agriculture Extension, Dera bugti, Balochistan-Pakistan

6. Department of Agronomy, Sindh Agriculture University, Tandojam-Pakistan

7. ADI Institute Usta Muhammad Jaffrabad Balochistan-Pakistan

8. Faculty of Agriculture, LUAWMS, Uthal-Pakistan

9. Soil fertility department Usta Muhammad at Jaffrabad-Pakistan

*Corresponding author's email: mithakhan86.mk@gmail.com

Citation

Syed Jahangeer Shah, Bhai Khan Solangi, Zulfiquar Ali, Sajid Ali Shah, Aziz Ullah, Kareem Bakhsh, Naveed Ahmed, Naseer Ahmed and Tariq Ali Mastoi. Screening of mustard varieties against sucking insect pests of mustard. Pure and Applied Biology.Vol. 9, Issue 2, pp1522-1531. http://dx.doi.org/10.19045/bspab.2020.90159

\begin{tabular}{llll}
\hline \hline Received: 14/11/2019 & Revised: 05/03/2020 & Accepted: 10/03/2020 & Online First: 16/03/2020 \\
\hline \hline
\end{tabular}

\section{Abstract}

The experiment was conducted at Mustard Oil Field, Agriculture Research Jaffarabad Seed Farm Usta Muhammad, Balochistan in a RCBD design with three replications to monitor the population dynamics of sucking insect pests on mustard.Five mustard varieties i.e. UCD-1202, NMT-8, Canola, Nawab Shah and P-25 was screened to evaluate the relative resistance against sucking insect pests. The monitoring of the sucking insect pests was started right from $15^{\text {th }}$ December, 2018 to $06^{\text {th }}$ March, 2019. The population buildup of each sucking insect pest was monitored at weekly interval. Highest infestation of whitefly $(0.98 \pm 0.29$ nymphs per plant) was recorded for Nawab Shah followed by P-25 $(0.92 \pm 0.26$ nymphs per plant), NMT-8 (0.89 \pm 0.25 nymphs per plant) and Canola $(0.82 \pm 0.22$ nymphs per plant), while lowest infestation $(0.77 \pm 0.21$ nymphs per plant) was observed for UCD-1202. Highest infestation of thrip (3.20 \pm 0.78 nymphs per plant) was recorded for Nawab Shah followed by P-25 $(3.08 \pm 0.75$ nymphs per plant), NMT-8 (2.97 \pm 0.70 nymphs per plant) and Canola (2.93 \pm 0.6 nymphs per plant), while lowest infestation (2.50 \pm 0.57 nymphs per plant) was observed for UCD-1202. Overall mean highest population of jassid $(0.74 \pm 0.20$ nymphs per plant) was recorded for Nawab Shah followed by P-25 $(0.60 \pm 0.30$ nymphs per plant), Canola (0.59 \pm 0.15 nymphs per plant) and NMT-8 (0.56 \pm 0.16 nymphs per plant), while lowest infestation $(0.19 \pm 0.05$ nymphs per plant) was observed for UCD-1202. Highest infestation aphid (21.80 \pm 10.28 nymphs per plant) was recorded for Nawab Shah followed by P-25 (20.78 \pm 10.10 nymphs per plant), NMT-8 (20.48 \pm 9.64 nymphs per plant) and Canola (18.85 \pm 9.07 nymphs per plant), while lowest infestation (18.27 \pm 9.04 nymphs per plant) was observed for UCD-1202.

Keywords: Mustard; Sucking insect pests; Varieties

Introduction

Rapeseed (Brassica spp.) is grown primarily

for its seed which yields about forty percent oil and a high-protein animal feed. The scientists have sequenced the entire genome of rapeseed/canola (Brassica napus) and its 
constituent genomes present in Brassica rapa and Brassica oleracea in 2009 [1]. Brassica napus (canola) is covered with more bloom than other species. It is very late in maturity and remains green untill about the middle of April. Canola has been especially developed for oil by the Canadian scientists. They have tried to reduce the amount of erucic acid in this newly bred variety. Canola oil is the lowest in saturated fat, containing only $6 \%$ saturated fat and is high in mono-saturated fat. This has $50 \%$ less saturated fat than corn oil [2].

The attack by insect pests and diseases are one of the key factors result of low yield. The mustard crop is more vulnerable to a extensive variety of insect pests from sowing till harvest than other oil seed crops. The insect pests of economic importance are, cabbage aphid, Brevicoryne brassica (L), mustard aphid, Lipaphis erysimi (Kalt.), mustard sawfly, Athalia proxima (Klug), cabbage butterfly, Pieris brassicae (Linn), Painted bug Bagrada picta (K), Mustard leaf eater, Spodaptera litura (F), leafminer, Chromatomyia horticola (Goureau) Thrip, Thrip tabaci and Whitefly, Bemesia tabaci (Gennedius) [3]. These insect-pests can be grouped as key pest, major pest and minor pest on the basis of their economic importance.

The infestation of sucking insect pests (white fly, thrips, jassid and aphid) is one of the main factors responsible for less yield of mustard. The mustard crop is highly vulnerable to a wide variety of insect pests from sowing till harvest than other oil seed crops [3]. The whiteflies are a limiting factor in the yield of mustard and rape seed. Whitefly (Bemisia tabaci Genn.) is small insect having four white membranous wings. The nymphs are oval and light yellow in colour and remain in clusters on the under surface of leaves. It breeds all the year, the eggs hatch in 3-6 days. Whitefly eggs are generally laid on the underside of leaves. The newly laid eggs are yellow/green, changing color to dark tan, as they are about to hatch. They are very small, oval shaped, and sit on top of a pedicel (stalk) that fits into a small slit in the leaf made by the female. Both nymphs and adults suck the sap from plants, reducing the vitality and yield of the crop. The nymphs secrete honeydew which promotes the growth of sooty mould [4].

The research is carried out worldwide to examine the varietal resistance and management of the sucking complex on oilseed crops. Rohilla et al. [5] reported that L. erysimi is most destructive insect causing severe reduction in seed yield varying from 15.0 to $73.3 \%$; while Verma et al. [3] found mustard aphid L. erysimi (Kalt.), Thrip $T$. tabaci and whitefly B. tabaci (Gennedius) as the major insect pests of mustard. Panda and Khush [6] found that varieties with thicker pods suppressed insect pest infestation and showed resistance in diseases transmitted by insects; while Karmakar [7] compared mustard cultivars B-9, NC-1, RW-351 and PGS-1004 for resistance to Lipaphis erysimi and found that lowest aphid population was recorded on PGS-1004 and this cultivar also showed higher yield than rest of the cultivars. Singh et al. [8] reported that Indian mustard (cv. Pusa Jai Kisan) showed relative resistance to L. erysimi; while Saljoqi et al. [9] reported that most of the hybrid mustard cultivars with thicker stems were resistant to L. erysimi and mustard sawfly. Sahito et al. [10] indicated that white fly B. tabaci, (Genn). mustard aphid L. erysimi (Kalt) and Bagrada picta $(\mathrm{F})$ were major mustard insect pests and Their population buildup was higher recorded on variety Yellow sarsoon 'Brown sarsoon' Das et al. [11] showed that relative humidity and rainfall had negative influence on pests and natural enemies during the study period. Bhati et al. [12] examined varietal resistance in rape-seed mustard and reported that mustard aphid, mustard sawfly, painted bug and cabbage butterfly were 
found attacking the mustard crop; while varieties BSH-1 and YST-151 showed higher susceptibility to mustard aphids as compared with brassica varieties Narendra Rai, GSC-6 and T-27. Singh et al. [8] reported that on variety YST-151 the aphid population was 2.9 larvae/10 plants showing susceptibility to sawfly. The proposed study is mainly aimed at evaluating the varietal resistance of mustard against sucking insect pests under field conditions.

\section{Materials and methods \\ Experimental area}

The experiment was conducted at Mustard Oil Field, Agriculture Research Jaffrabad Seed Farm Usta Muhammad, Balochistan.

\section{Experimental design}

The experiment was laid out in a Randomized Complete Block Design (RCBD) having net plot size of $5 \times 1.2 \mathrm{~m}$ with three replications to monitor the population dynamics of sucking insect pests on mustard.

\section{Selection of mustard cultivars}

Five mustard varieties i.e. UCD-1202, NMT8, Canola, Nawab Shah and P-25 and was screened to evaluate the relative resistance against sucking insect pests.

\section{Monitoring and data collection}

The monitoring of the sucking insect pests was started right from $15^{\text {th }}$ December, 2018 to $06^{\text {th }}$ March, 2019. The population buildup of each sucking insect pest was monitored at weekly interval. The observations regarding the sucking insect pest population was noted on the basis of randomly selected five plants from top, middle and bottom for each mustard variety. The sucking insect pests were identified and recorded their population in separate data recording sheets weekly.

\section{Data analysis}

Data was analysed using descriptive statistics (Statistix ver. 8.1). The significance of the differences in population level of the insect pests was evaluated using analysis of variance and least significant difference test.

\section{Results \\ Population of whitefly}

Population fluctuation of whitefly in different mustard varieties was determined from $15^{\text {th }}$ December, 2018 to $06^{\text {th }}$ March, 2019. Statistical analysis of the data showed significant difference in population flcutation of whitefly among the mustard varieties and weeks as well as their interactions. The data (Table 1) indicates that on $15^{\text {th }}$ December, 2018 the whitefly population was recorded as $1.40 \pm 0.67,1.60 \pm 0.62,1.33 \pm 0.62,1.86 \pm 0.11$ and $1.66 \pm 0.64$ nymphs per plant in variety UCD-1202, NMT-8, Canola, Nawab Shah and $\mathrm{P}-25$, respectively. The whitefly population started increasing from $22^{\text {nd }}$ December, 2019 and the population reached at peak level on $07^{\text {th }}$ January, 2019 with average $1.86 \pm 0.65,2.26 \pm 0.90,2.06 \pm 0.95$, $2.86 \pm 0.42$ and $2.40 \pm 0.69$ nymphs per plantin variety UCD-1202, NMT-8, Canola, Nawab Shah and P-25, respectively. After $16^{\text {th }}$ January, 2019 the population of whitefly gradually decreases and reached upto lowest level on $02^{\text {nd }} F e b r u a r y, ~ 2019$ with average $0.33 \pm 0.06,0.33 \pm 0.14,0.40 \pm 0.02,0.13 \pm 0.06$ and $0.20 \pm 0.03$ nymphs per plant in variety UCD-1202, NMT-8, Canola, Nawab Shah and P-25, respectively. Whitefly population was recorded as zero in four observations from $16^{\text {th }}$ February to $06^{\text {th }}$ March, 2019. On average highest infestation $(0.98 \pm 0.29$ nymphs per plant) was noted for Nawab Shah followed by P-25 $(0.92 \pm 0.26$ nymphs per plant), NMT-8 ( $0.89 \pm 0.25$ nymphs per plant) and Canola (0.82 \pm 0.22 nymphs per plant), while lowest infestation $(0.77 \pm 0.21$ nymphs per plant) was observed for UCD-1202.

\section{Population of thrips}

Population fluctuation of thrips in different mustard varieties was determined from $15^{\text {th }}$ December, 2018 to $06^{\text {th }}$ March, 2019. Statistical analysis of the data showed significant difference in population flcutation of thrips among the mustard varieties, while non-significant difference between their 
interactions. The data (Table 2) indicates that on $15^{\text {th }}$ December, 2018 the thrip population was recorded as 3.26 $\pm 0.67,4.80 \pm 0.32$, $5.20 \pm 0.29,5.06 \pm 0.12$ and $4.66 \pm 0.54$ nymphs per plant in variety UCD-1202, NMT-8, Canola, Nawab Shah and P-25, respectively. The thrip population started increasing from $22^{\text {nd }}$ December, 2018 and the population reached at peak level on $07^{\text {th }}$ January, 2019 with average $6.60 \pm 0.57, \quad 7.93 \pm 0.84$, $6.53 \pm 0.26,8.13 \pm 0.35$ and $8.26 \pm 0.94$ nymphs per plantin variety UCD-1202, NMT-8, Canola, Nawab Shah and P-25, respectively. After $16^{\text {th }}$ January, 2019 the population of thrips gradually decreases and reached upto lowest level on $24^{\text {th }}$ February, 2019 with average $0.20 \pm 0.00,0.13 \pm 0.26,0.53 \pm 0.16$, $0.40 \pm 0.35$ and $0.60 \pm 0.11$ nymphs per plant in variety UCD-1202, NMT-8, Canola, Nawab Shah and P-25, respectively. Thrips population was recorded as zero in last two observations viz., $30^{\text {th }}$ February to $06^{\text {th }}$ March, 2019. On average highest infestation (3.20 \pm 0.78 nymph per plant) was noted for Nawab Shah followed by P-25 $(3.08 \pm 0.75$ nymph per plant), NMT-8 (2.97 \pm 0.70 nymphs per plant) and Canola $(2.93 \pm 0.6$ nymphs per plant), while lowest infestation (2.50 \pm 0.57 nymphs per plant) was observed for UCD-1202.

\section{Population of jassid}

Population fluctuation of jassid in different mustard varieties was determined from $15^{\text {th }}$ December, 2018 to $06^{\text {th }}$ March, 2019. Statistical analysis of the data showed significant difference in population flcutation of jassid among the mustard varieties and weeks as well as their interactions. The data (Table 3) indicates that on $16^{\text {th }}$ January, 2019 the jassid population was recorded as $0 \pm 0$, $0 \pm 0, \quad 0.90 \pm 0.52, \quad 0.30 \pm 0.10$ and $0.50 \pm 0.22$ nymphs per plant in variety UCD-1202, NMT-8, Canola, Nawab Shah and P-25, respectively. The jassid population was gradually increased from $24^{\text {th }}$ January to $06^{\text {th }}$ March, 2019 in all five varieties. The peak population of jassid was recorded on $06^{\text {th }}$ March, 2019 i.e. $0.90 \pm 0.46, \quad 1.66 \pm 0.62$, $1.40 \pm 0.49,1.98 \pm 0.58$ and $1.20 \pm 0.51$ nymphs per plant in variety UCD-1202, NMT-8, Canola, Nawab Shah and P-25, respectively. On average highest infestation $(0.74 \pm 0.20$ nymphs per plant) was noted for

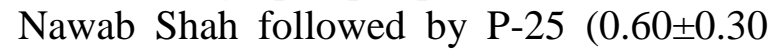
nymphs per plant), Canola $(0.59 \pm 0.15$ nymphs per plant) and NMT-8 $(0.56 \pm 0.16$ nymphs per plant $)$, while lowest infestation $(0.19 \pm 0.05$ nymphs per plant) was observed for UCD-1202.

Table 1. Population fluctuation of whitefly in different mustard cultivars

\begin{tabular}{|c|c|c|c|c|c|}
\hline \multirow[b]{2}{*}{ Date } & \multicolumn{5}{|c|}{ Varieties } \\
\hline & UCD-1202 & NMT-8 & CANOLA & $\begin{array}{c}\text { NAWAB } \\
\text { SHAH }\end{array}$ & P-25 \\
\hline $15^{\text {th }}$ December, 2018 & $1.40 \pm 0.67$ & $1.60 \pm 0.62$ & $1.33 \pm 0.62$ & $1.86 \pm 0.11$ & $1.66 \pm 0.64$ \\
\hline $22^{\text {nd }}$ December, 2018 & $1.66 \pm 0.82$ & $1.93 \pm 0.82$ & $1.66 \pm 0.82$ & $2.00 \pm 0.36$ & $1.86 \pm 0.85$ \\
\hline $30^{\text {th }}$ December, 2018 & $1.73 \pm 0.93$ & $2.00 \pm 0.94$ & $1.73 \pm 0.90$ & $2.06 \pm 0.82$ & $2.20 \pm 0.93$ \\
\hline $07^{\text {th }}$ January, 2019 & $1.86 \pm 0.65$ & $2.26 \pm 0.90$ & $2.06 \pm 0.95$ & $2.86 \pm 0.42$ & $2.40 \pm 0.69$ \\
\hline $16^{\text {th }}$ January, 2019 & $1.20 \pm 0.32$ & $1.33 \pm 0.22$ & $1.13 \pm 0.16$ & $1.33 \pm 0.36$ & $1.26 \pm 0.32$ \\
\hline $24^{\text {th }}$ January, 2019 & $0.53 \pm 0.25$ & $0.93 \pm 0.16$ & $1.00 \pm 0.10$ & $1.00 \pm 0.04$ & $1.06 \pm 0.14$ \\
\hline $31^{\text {st }}$ January, 2019 & $0.60 \pm 0.13$ & $0.33 \pm 0.11$ & $0.53 \pm 0.06$ & $0.53 \pm 0.02$ & $0.46 \pm 0.10$ \\
\hline $08^{\text {th }}$ February, 2019 & $0.33 \pm 0.06$ & $0.33 \pm 0.14$ & $0.40 \pm 0.02$ & $0.13 \pm 0.06$ & $0.20 \pm 0.03$ \\
\hline $16^{\text {th }}$ February, 2019 & $0.00 \pm 0.00$ & $0.00 \pm 0.00$ & $0.00 \pm 0.00$ & $0.00 \pm 0.00$ & $0.00 \pm 0.00$ \\
\hline $24^{\text {th }}$ February, 2019 & $0.00 \pm 0.00$ & $0.00 \pm 0.00$ & $0.00 \pm 0.00$ & $0.00 \pm 0.00$ & $0.00 \pm 0.00$ \\
\hline $30^{\text {th }}$ February, 2019 & $0.00 \pm 0.00$ & $0.00 \pm 0.00$ & $0.00 \pm 0.00$ & $0.00 \pm 0.00$ & $0.00 \pm 0.00$ \\
\hline $06^{\text {th }}$ March, 2019 & $0.00 \pm 0.00$ & $0.00 \pm 0.00$ & $0.00 \pm 0.00$ & $0.00 \pm 0.00$ & $0.00 \pm 0.00$ \\
\hline Overall Mean+SE & $0.77 \pm 0.21$ & $0.89 \pm 0.25$ & $0.82 \pm 0.22$ & $0.98 \pm 0.29$ & $0.92 \pm 0.26$ \\
\hline
\end{tabular}


Table 2. Population fluctuation of thrips in different mustard cultivars

\begin{tabular}{|c|c|c|c|c|c|}
\hline \multirow[b]{2}{*}{ Date } & \multicolumn{5}{|c|}{ Varieties } \\
\hline & UCD-1202 & NMT-8 & CANOLA & $\begin{array}{c}\text { NAWAB } \\
\text { SHAH }\end{array}$ & P-25 \\
\hline $15^{\text {th }}$ December, 2018 & $3.26 \pm 0.67$ & $4.80 \pm 0.32$ & $5.20 \pm 0.29$ & $5.06 \pm 0.12$ & $4.66 \pm 0.54$ \\
\hline $22^{\text {nd }}$ December, 2018 & $3.73 \pm 0.16$ & $4.86 \pm 0.42$ & $5.73 \pm 0.34$ & $5.53 \pm 0.19$ & $5.53 \pm 0.62$ \\
\hline $30^{\text {th }}$ December, 2018 & $4.73 \pm 0.34$ & $5.06 \pm 0.36$ & $6.20 \pm 0.65$ & $7.06 \pm 0.21$ & $5.60 \pm 0.84$ \\
\hline $07^{\text {th }}$ January, 2019 & $6.60 \pm 0.57$ & $7.93 \pm 0.84$ & $6.53 \pm 0.26$ & $8.13 \pm 0.35$ & $8.26 \pm 0.94$ \\
\hline $16^{\text {th }}$ January, 2019 & $3.20 \pm 0.25$ & $3.80 \pm 0.65$ & $3.40 \pm 0.32$ & $3.13 \pm 0.08$ & $4.40 \pm 0.35$ \\
\hline $24^{\text {th }}$ January, 2019 & $2.73 \pm 0.36$ & $2.86 \pm 0.23$ & $2.53 \pm 0.64$ & $3.00 \pm 0.24$ & $3.00 \pm 0.21$ \\
\hline $31^{\text {st }}$ January, 2019 & $2.40 \pm 0.84$ & $2.40 \pm 0.33$ & $1.93 \pm 0.29$ & $2.26 \pm 0.32$ & $2.13 \pm 0.16$ \\
\hline $08^{\text {th }}$ February, 2019 & $1.80 \pm 0.72$ & $2.40 \pm 0.15$ & $1.80 \pm 0.34$ & $2.20 \pm 0.11$ & $1.46 \pm 0.29$ \\
\hline $16^{\text {th }}$ February, 2019 & $1.40 \pm 0.64$ & $1.46 \pm 0.10$ & $1.40 \pm 0.28$ & $1.73 \pm 0.14$ & $1.40 \pm 0.36$ \\
\hline $24^{\text {th }}$ February, 2019 & $0.20 \pm 0.00$ & $0.13 \pm 0.26$ & $0.53 \pm 0.16$ & $0.40 \pm 0.35$ & $0.60 \pm 0.11$ \\
\hline 30 $0^{\text {th }}$ February, 2019 & $0.00 \pm 0.00$ & $0.00 \pm 0.00$ & $0.00 \pm 0.00$ & $0.00 \pm 0.00$ & $0.00 \pm 0.00$ \\
\hline $06^{\text {th }}$ March, 2019 & $0.00 \pm .00$ & $0.00 \pm 0.00$ & $0.00 \pm 0.00$ & $0.00 \pm 0.00$ & $0.00 \pm 0.00$ \\
\hline Overall Mean \pm SE & $2.50 \pm 0.57$ & $2.97 \pm 0.70$ & $2.93 \pm 0.69$ & $3.20 \pm 0.78$ & $3.08 \pm 0.75$ \\
\hline
\end{tabular}

Table 3. Population fluctuation of jassid in different mustard cultivars

\begin{tabular}{|c|c|c|c|c|c|}
\hline \multirow{2}{*}{ Date } & \multicolumn{5}{|c|}{ Varieties } \\
\cline { 2 - 6 } & UCD-1202 & NMT-8 & CANOLA & $\begin{array}{c}\text { NAWAB } \\
\text { SHAH }\end{array}$ & P-25 \\
\hline $15^{\text {th }}$ December, 2018 & $0 \pm 0$ & $0 \pm 0$ & $0 \pm 0$ & $0 \pm 0$ & $0 \pm 0$ \\
\hline $22^{\text {nd }}$ December, 2018 & $0 \pm 0$ & $0 \pm 0$ & $0 \pm 0$ & $0 \pm 0$ & $0 \pm 0$ \\
\hline $30^{\text {th }}$ December, 2018 & $0 \pm 0$ & $0 \pm 0$ & $0 \pm 0$ & $0 \pm 0$ & $0 \pm 0$ \\
\hline $07^{\text {th }}$ January, 2019 & $0 \pm 0$ & $0 \pm 0$ & $0 \pm 0$ & $0 \pm 0$ & $0 \pm 0$ \\
\hline $16^{\text {th }}$ January, 2019 & $0 \pm 0$ & $0 \pm 0$ & $0.90 \pm 0.52$ & $0.30 \pm 0.10$ & $0.50 \pm 0.22$ \\
\hline $24^{\text {th }}$ January, 2019 & $0.15 \pm 0.21$ & $0.17 \pm 0.10$ & $0.10 \pm 0.03$ & $0.40 \pm 0.22$ & $0.11 \pm 0.03$ \\
\hline $31^{\text {st }}$ January, 2019 & $0 \pm 0$ & $0.40 \pm 0.21$ & $0.36 \pm 0.19$ & $0.90 \pm 0.36$ & $0.30 \pm 0.19$ \\
\hline $08^{\text {th }}$ February, 2019 & $0.10 \pm 0.03$ & $0.96 \pm 0.36$ & $0.70 \pm 0.25$ & $1.20 \pm 0.52$ & $1.71 \pm 0.65$ \\
\hline $16^{\text {th }}$ February, 2019 & $0.20 \pm 0.05$ & $1.0 \pm 0.58$ & $1.10 \pm 0.16$ & $1.20 \pm 0.50$ & $1.10 \pm 0.28$ \\
\hline $24^{\text {th }}$ February, 2019 & $0.40 \pm 0.10$ & $1.26 \pm 0.62$ & $1.30 \pm 0.32$ & $1.40 \pm 0.62$ & $0.75 \pm 0.42$ \\
\hline $30^{\text {th }}$ February, 2019 & $0.60 \pm 0.30$ & $1.30 \pm 0.22$ & $1.22 \pm 0.52$ & $1.50 \pm 0.46$ & $1.55 \pm 0.32$ \\
\hline $06^{\text {th }}$ March, 2019 & $0.90 \pm 0.46$ & $1.66 \pm 0.62$ & $1.40 \pm 0.49$ & $1.98 \pm 0.58$ & $1.20 \pm 0.51$ \\
\hline Overall Mean \pm SE & $\mathbf{0 . 1 9} \pm \mathbf{0 . 0 5}$ & $\mathbf{0 . 5 6} \pm \mathbf{0 . 1 6}$ & $\mathbf{0 . 5 9} \pm \mathbf{0 . 1 5}$ & $\mathbf{0 . 7 4} \pm \mathbf{0 . 2 0}$ & $\mathbf{0 . 6 0 \pm 0 . 3 0}$ \\
\hline
\end{tabular}

\section{Population of aphids}

Population fluctuation of aphids in different mustard varieties was determined from $15^{\text {th }}$ December, 2018 to $06^{\text {th }}$ March, 2019. Statistical analysis of the data showed significant difference in population flcutation of aphids among the mustard varieties and weeks as well as their interactions. The data (Table 4) indicates that on $15^{\text {th }}$ December, 2018 the aphid population was recorded as $0.02 \pm 0.00,0.02 \pm 00,0.06 \pm 0.01,0.10 \pm 0.02$ and $0.40 \pm 0.06$ nymphs per plant in variety UCD-1202, NMT-8, Canola, Nawab Shah and P-25, respectively. The aphid population was gradually increased from $22^{\text {nd }}$ January to $31^{\text {st }}$ January, 2019 in all five varieties. The aphids population increased upto $5.86 \pm 0.82$, $5.53 \pm 0.89, \quad 6.00 \pm 0.52, \quad 5.53 \pm 0.65$ and $5.53 \pm 0.32$ nymphs per plantin variety UCD1202, NMT-8, Canola, Nawab Shah and P25 , respectively. After $08^{\text {th }}$ February, 2019 the population of aphid continuously increases in linear trend and reached upto highest level on $06^{\text {th }}$ March, 2019 with average $100.87 \pm 8.22$, $101.80 \pm 8.10,99.33 \pm 8.60,111.80 \pm 8.22$ and $111.47 \pm 8.94$ nymphs per plant in variety UCD-1202, NMT-8, Canola, Nawab Shah and $\mathrm{P}-25$, respectively. On average highest 
infestation $(21.80 \pm 10.28$ nymphs per plant $)$ was noted for Nawab Shah followed by P-25 (20.78 \pm 10.10 nymphs per plant), NMT-8 (20.48 \pm 9.64 nymphs per plant) and Canola
(18.85 \pm 9.07 nymphs per plant), while lowest infestation (18.27 \pm 9.04 nymphs per plant) was observed for UCD-1202.

Table 4. Population fluctuation of aphids in different mustard varieties from 25-12-2017 to 12-03-2018

\begin{tabular}{|c|c|c|c|c|c|}
\hline \multirow{2}{*}{ Date } & \multicolumn{5}{|c|}{ Varieties } \\
\cline { 2 - 6 } & UCD-1202 & NMT-8 & CANOLA & $\begin{array}{c}\text { NAWAB } \\
\text { SHAH }\end{array}$ & P-25 \\
\hline $15^{\text {th }}$ December, 2018 & $0.02 \pm 0.00$ & $0.02 \pm 00$ & $0.06 \pm 0.01$ & $0.10 \pm 0.02$ & $0.40 \pm 0.06$ \\
\hline $22^{\text {nd }}$ December, 2018 & $0.06 \pm 0.02$ & $0.06 \pm 0.01$ & $0.06 \pm 0.01$ & $0.13 \pm 0.05$ & $0.46 \pm 0.10$ \\
\hline $30^{\text {th }}$ December, 2018 & $0.40 \pm 0.06$ & $0.33 \pm 0.03$ & $0.66 \pm 0.22$ & $0.33 \pm 0.11$ & $0.53 \pm 0.16$ \\
\hline $07^{\text {th }}$ January, 2019 & $0.60 \pm 0.10$ & $0.40 \pm 0.14$ & $0.13 \pm 0.06$ & $0.46 \pm 0.21$ & $0.53 \pm 0.32$ \\
\hline $16^{\text {th }}$ January, 2019 & $0.73 \pm 0.50$ & $0.60 \pm 0.23$ & $0.46 \pm 0.24$ & $0.60 \pm 0.26$ & $1.20 \pm 0.58$ \\
\hline $24^{\text {th }}$ January, 2019 & $0.93 \pm 0.62$ & $0.93 \pm 0.31$ & $1.00 \pm 0.32$ & $1.20 \pm 0.35$ & $1.20 \pm 0.52$ \\
\hline $31^{\text {st }}$ January, 2019 & $5.86 \pm 0.82$ & $5.53 \pm 0.89$ & $6.00 \pm 0.52$ & $5.53 \pm 0.65$ & $5.53 \pm 0.32$ \\
\hline $08^{\text {th }}$ February, 2019 & $10.06 \pm 1.28$ & $12.26 \pm 1.68$ & $11.73 \pm 1.11$ & $10.73 \pm 1.22$ & $10.60 \pm 1.20$ \\
\hline $16^{\text {th }}$ February, 2019 & $11.80 \pm 2.50$ & $13.13 \pm 2.58$ & $12.13 \pm 2.88$ & $25.20 \pm 2.64$ & $14.13 \pm 2.10$ \\
\hline $24^{\text {th }}$ February, 2019 & $28.53 \pm 3.11$ & $40.26 \pm 3.22$ & $32.20 \pm 3.52$ & $32.73 \pm 5.88$ & $35.00 \pm 3.58$ \\
\hline $30^{\text {th }}$ February, 2019 & $59.46 \pm 5.10$ & $70.46 \pm 5.88$ & $62.46 \pm 5.62$ & $72.93 \pm 6.99$ & $68.40 \pm 5.22$ \\
\hline $06^{\text {th }}$ March, 2019 & $100.87 \pm 8.22$ & $101.80 \pm 8.10$ & $99.33 \pm 8.60$ & $111.80 \pm 8.22$ & $111.47 \pm 8.94$ \\
\hline Overall Mean \pm SE & $\mathbf{1 8 . 2 7} \pm \mathbf{9 . 0 4}$ & $\mathbf{2 0 . 4 8 \pm 9 . 6 4}$ & $\mathbf{1 8 . 8 5} \pm \mathbf{9 . 0 7}$ & $\mathbf{2 1 . 8 0 \pm 1 0 . 2 8}$ & $\mathbf{2 0 . 7 8 \pm 1 0 . 1 0}$ \\
\hline
\end{tabular}

\section{Crop Yield $\left(\mathrm{kg} \mathrm{ha}^{-1}\right)$}

Results in regards to crop yield is presented in (Fig. 1). Statistical analysis of the obtained data indicated that there was significant difference in crop yield between all the five mustard varieties. On the basis of average, the maximum crop yield $\left(1850.53 \mathrm{~kg} \mathrm{plot}^{-1}\right)$ was recorded for UCD-1202 followed by NMT-8 (1560.2 kg plot $\left.{ }^{-1}\right)$, P-25 (1540.5 kg $\left.\mathrm{plot}^{-1}\right)$ and Canola $\left(1520.3 \mathrm{~kg} \mathrm{plot}^{-1}\right)$ and the minimum crop yield (1498.8 $\mathrm{kg} \mathrm{ha}^{-1}$ ) was noted for Nawab Shah mustard variety.

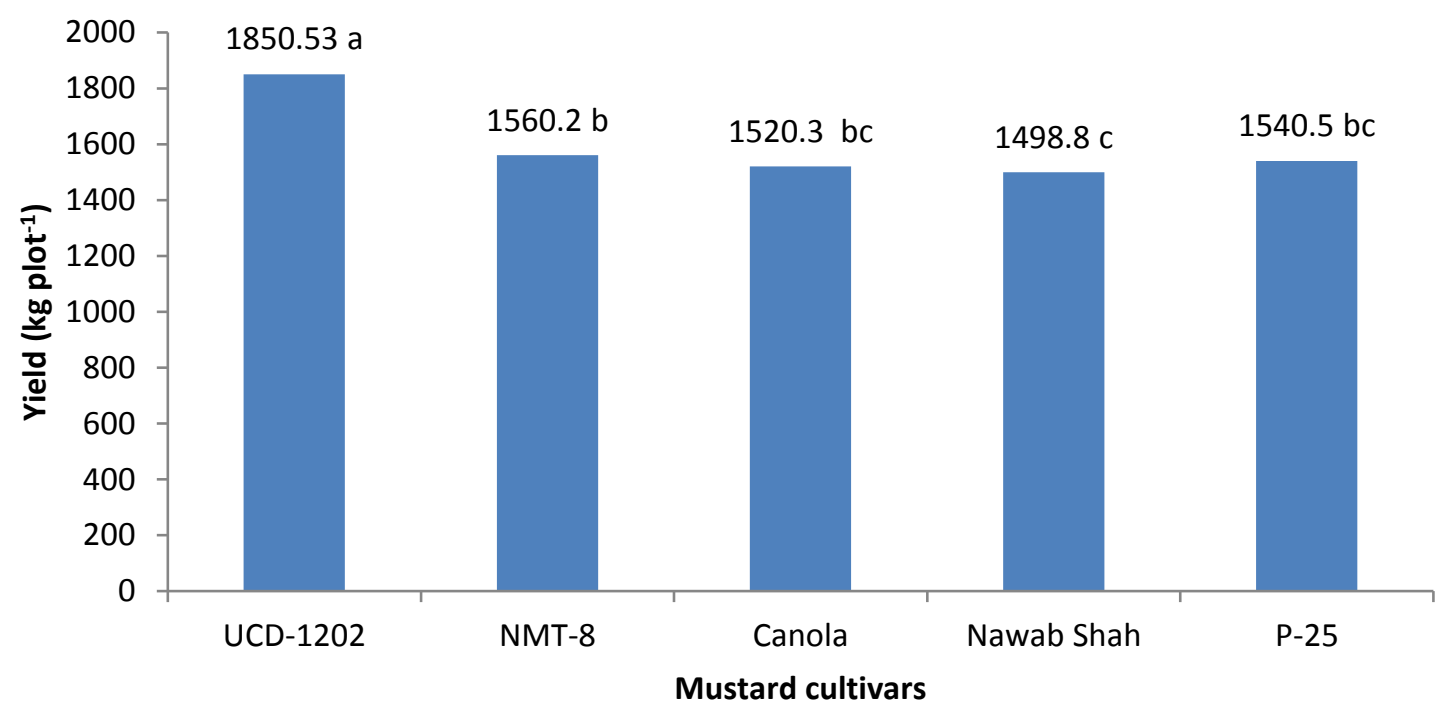

Figure 1. Yield $\left(\mathrm{kg} \mathrm{ha}^{-1}\right)$ of different mustard varieties 


\section{Discussion}

The infestation of sucking insect pests (white fly, thrips, jassid and aphid) is one of the important factors responsible for below yield of mustard. The mustard crop is more vulnerable to a wide variety of insect pests from sowing till harvest compared to other oil seed crops [3]. The research is carried out worldwide to examine the varietal resistance and management of the sucking complex on oilseed crops.

The findings of the study indicated that highest whitefly population was recorded on Nawab Shah Variety and the lowest whitefly population was recorded on variety UCD1202. The LSD test suggested that the differences in whitefly population among mustard varieties were statistically significant $(\mathrm{P}<0.05)$. These results are further supported by Rohilla et al. [5] who reported that whitefly population varied significantly among mustard varieties; while Bhatti and Soomro [13] showed that mustard varieties with tricons showed resistance to whitefly; while varieties having leaves without tricons suffered with more infestation of sucking insect pests. In another study, Panda and Khush [6] observed that development of mustard varieties resistant to sucking complex could increase the seed yield manifold; while Rangrez et al. [14] reported varied response of mustard varieties to whitefly infestation. The crop varieties play significant role in insect pest infestation; as varieties preferred by insect pests are economically harmful for the farmers. Cultivation of insect-resistant crop varieties may suppress insect pest infestation and control plant diseases transmitted by insects. If there are persistent viruses, plant resistance to their transmitters usually reduce virusspread by slowing down their replication [6]. If pest resistant varieties are used with chemical control methods, the costs of chemical control and problems related to insecticides may be reduced [15].
Consequently, the use of resistant plant varieties plays an important role in reducing environmental pollution. There are several factors that make resistant plants inappropriate host plant species for pests [16]. Different parts of a plant, the leaf age and the hairy leaves are effective for feeding and egg laying, selection and changes in the B. tabaci populations on rapeseed-mustard [1]. Fuzz and fluffs can be a physical barrier and also provide a suitable microclimate for vegetarians [17]. There are several defense mechanisms against pests, such as: the number and type of trichoms [18], and chemicals substances as well as the pod thickness [12]. Leidl et al. [19] examined varietal resistance in rape-seed mustard and reported that mustard aphid, mustard sawfly, painted bug and cabbage butterfly were found attacking the mustard crop; while varieties BSH-1 and YST-151 showed higher susceptibility to mustard aphids as compared with brassica varieties Narendra Rai, GSC-6 and T-27. Singh et al. [8] reported that on variety YST-151 the aphid population was 2.9 larvae/10 plants showing susceptibility to sawfly. Sahito et al. [10] indicated that Bemisia tabaci, (Genn). was one of themajor mustard insect pests and showed that higher $(6.71+0.98 /$ leaf $)$ population of B. tabaci was recorded on Yellow sarsoon than Dark green leaves $(6.30+0.61)$, Brown sarsoon $(6.19+$ $0.63)$, Raya Anmol (5.40 + 0.55), Torya Early $(5.38+0.57)$ and Rai S-9 (3.79+0.50). Das et al. [11] showed that relative humidity and rainfall had negative influence on pests and natural enemies during the study period. The study showed that the thrips population was highest on variety Nawab Shah variety and lowest thrips population was observed on UCD-1202 variety. This indicates that variety 'UCD-1202' showed higher relative resistance to thrips when compared with rest of the varieties. The LSD test indicated that the differences in thrips population among mustard varieties were statistically 
significant $(\mathrm{P}<0.05)$. The validity of varietal resistance to insect pests in oilseeds has also been argued by Henriksen [20]. Hausammann [21]. Rangrez et al. [14] reported that thrips population apart from the environmental factors varied significantly on mustard varieties of diversified origin. Verma, et al. [3] found thrip, Thrip tabaci as the major insect pest of mustard. Panda and Khush [6] found that varieties with thicker pods suppressed insect pest infestation and showed resistance in diseases transmitted by insects. Singh et al. [8] found that thrip population on mustard varieties with thicker stems was lower than thin stemmed varieties. Verma et al. [3] experienced a great variation in the thrip population among different mustard cultivars. Similar results have also been reported by Hausammann [21] and Jessop et al. [22]. Malik et al. [23] argued that mustard varieties with rsistance against sucking complex, particularly jassid is of great economic importance.

The study showed that the jassid population was highest on variety Nawab Shah variety and lowest jassid population was observed on UCD-1202 variety. This indicates that variety 'UCD-1202' showed higher relative resistance to jassid when compared with rest of the varieties. The LSD test indicated that the differences in jassid population among mustard varieties were statistically significant $(\mathrm{P}<0.05)$. Panda and Khush [6] found that jassid population on mustard varieties with thicker stems was lower than thin stemmed varieties. Verma et al. [3] experienced a great variation in the jassid population among different mustard cultivars. Malik et al. [23] argued that mustard varieties with rsistance against sucking complex, particularly jassid is of great economic importance.

The findings of the study indicated that highest aphid population was recorded on Nawab Shah variety and the lowest aphid population was recorded on variety UCD-
1202. The LSD test suggested that the differences in aphid population among mustard varieties were statistically significant $(\mathrm{P}<0.05)$. The sucking insect pest resistance trend suggested that UCD-1202 may preferably be cultivated having some resistance to sucking insect pests. These results are in accordance with those of Rohilla et al. [5] who reported that L. erysimi is most destructive insect causing severe reduction in seed yield varying from 15.0 to 73.3\%; while Verma, et al. [3] found mustard aphid, Lipaphis erysimi (Kalt.), as the major insect pest of mustard. Panda and Khush [6] found that varieties with thicker pods suppressed insect pest infestation and showed resistance in diseases transmitted by insects; while Karmakar [24] compared mustard cultivars B-9, NC-1, RW-351 and PGS-1004 for resistance to Lipaphis erysimi and found that lowest aphid population was recorded on PGS-1004 and this cultivar also showed higher yield than rest of the cultivars. Singh et al. [8] reported that Indian mustard (cv. Pusa Jai Kisan) showed relative resistance to Lipaphis erysimi; while Saljoqi et al. [25] reported that most of the hybrid mustard cultivars with thicker stems were resistant to Lipaphis erysimi and mustard sawfly. Sahito et al. [10] indicated that Lipaphis erysimi (Kalt) was the major mustard insect pest and showed that higher aphid population was noted on Yellow sarsoon than Dark green leaves, Brown sarsoon, Raya Anmol, Torya Early and Rai S-9. Das et al. [11] showed that environmental factors had also significant impact on the insect pest population.

\section{Conclusion}

It is concluded that maximum infestation of whitefly, thrip, jassid and aphid was observed for variety 'Nawab Shah' and minimum was observed for variety 'UCD-1202'. The peak infestation of the sucking complex was observed in the month of January in all five mustard varieties. 


\section{Authors' contributions}

Conceived and designed the experiments: SJ Shah \& BK Solangi, Performed the experiments: SJ Shah \& SA Shah, Analyzed the data: SJ Shah, Z Ali \& Azizullah, Contributed materials/ analysis/ tools: K Bakhsh, N Ahmed \& N Ahmed, Wrote the paper: SJ Shah, T Ali \& BK Solangi.

\section{References}

1. Fekri MS, Samih MA, Imani S \& Zarabi M (2013). Study of host preference and the comparison of some biological characteristics of Bemisia tabasi (Genn.) on mustard varieties. $J$ of Plant Protec Res 53(2): 47-52.

2. Pradhan TS (2012). Status of insect pests of cruciferous in U.P. India. Indian $J$ of Agric Res 12:45-50.

3. Verma, et al. (2016). Relative abundance of aphids population on different brassica genotypes. Sarhad J of Agric 29(1): 133-138.

4. Jech LE \& Husman SH (2015). Screening of different cultivars of rapeseed-mustard against mustard aphid, Lipaphis erysimi, Kaltenbach with respect to sowing dates. Asian J of Plant Sci 10(2): 383-392.

5. Rohilla et al. (1990. Insect-pests and their management in rapeseed-mustard. $J$ of Oilseeds Res 6(2): 147-151.

6. Panda \& Khush, (1995). Observations on the economic threshold level of the mustard aphid, Lipaphis erysimi (Kaltenbach) on mustard in Bangladesh. Bangla J of Zool 23(1): 13-16.

7. Karmakar (2003). Impact of honey bee pollination on pod set of mustard (Brassica juncea L. Cruciferae) at pantnagar. Inter Quarterly J of Life Sci 9(1): 75-78.

8. Singh et al. (2015). Integrated pest and disease management in mustard: an economic analysis. Agric Econ Res Rev 26(2): 269-280.
9. Saljoqi et al. (2011). Bemisia tabaci: effect of cotton leaf pubescence on abundance. J of Southwest Entomol 9(1): 91-94.

10. Sahito et al. (2010). Acylsugars of wild mustard Lycopersicon pennellii alters settling and reduces oviposition of Bemisia argentifolii (Homoptera: Aleyrodidae). $J$ of Econ and Entomol 88(3): 742-748.

11. Das B, Patra S, Alam SF \& Chaterjee ML (2013). Population dynamics of major insect pests and their natural enemies on cabbage under new alluvial zone of West Bengal. The J of Plant Protec Sci 5(1): 42-49.

12. Bhati R, Sharma RC \& Singh R (2015). Studies on occurrence of insect-pests of different Brassica species. Inter $J$ of Curr Sci 14(1): 125-132.

13. Bhatti \& Soomro, (1996). Impact of honey bee pollination on pod set of mustard (Brassica juncea L. Cruciferae) at pantnagar. Inter Quarterly J of Life Sci 9(1): 75-78.

14. Rangrez et al. (2003). Attractancy and oviposition response of type IV trichome density on leaves of Lycopersicon esculentum grown in three day-lenght regimes. J of Entomol Sci 33(3): 270281.

15. Panda \& Khush (1995). Quantification of avoidable yield losses in oilseed Brassica caused by insect pests. $J$ of Plant Protec Res 51(2): 211-220.

16. Samih (2005). Effect of date of sowing on the incidence of insect pests of rape and mustard. J of Interacademicia 7(4): 420-425.

17. Willmer (1986). Validation of IPM of mustard fruit borer using NPV sprays and marigold as trap crop. In: Proceedings of the Symposium on Biological Control of Lepidopteran Pests, Eds: PL Tandon, CR Ballal, SK 
Jalali and RJ Rabindra, Bangalore, pp 261-265.

18. Snyder et al. (1998). Ecological studies on aphid, painted bug and sawfly attacking mustard and rapeseed in India. FAO PL Protec Bull 20(6): 136-140.

19. Leidl et al. (1995). Pest complex of mustard crop and relative efficacy of some important insecticides against important insect-pests of mustard crop. $J$ of Entomol 2(2): 119.

20. Henriksen (1999). Non preference of whitefly for oviposition in mustard genotypes. J of Sci Agric 59(4): 112-117.

21. Hausammann (1996). Influence of plant age, whitefly population and cultivar resistance on infection of cotton plants by cotton leaf curl virus (CLCuV) in Pakistan. Field Crops Res 86(1): 15-21.
22. Jessop et al. (1996). Studies of some insecticides and bio pesticides on foraging behaviour of honey bees in mustard (Brassicajuncea L.). Asian $J$ of Biol Sci 7(2): 214-215.

23. Malik et al. (2012). Bioecology of painted bug (Bagrada cruciferarum) (Hemiptera: Pentatomidae) on seed crop of cauliflower (Brassica oleracea). Indian J Agric Sci 63(10): 676-678.

24. Karmakar (2003). Pest complex of Indian mustard, Brassica juncea, in eastern Rajasthan. Indian $J$ of Entomol 68(2): 48-149.

25. Saljoqi et al. (2006). Effect of some pesticides on foraging activities of different species of honey bees in mustard (Brassica juncea L.). Inter $J$ of Agric Sci 7(1): 167-168. 